\title{
DISASTER PREPAREDNESS: SURVEY STUDY PADA MAHASISWA KEPERAWATAN UNIVERSITAS HARAPAN BANGSA PURWOKERTO
}

\author{
Azka Fathiyatir Rizqillah \\ Program Studi Keperawatan, Fakultas Kesehatan, Universitas Harapan Bangsa Purwokerto, Jawa Tengah \\ Email : azkafathiyatir@shb.ac.id
}

\begin{abstract}
ABSTRAK
Latar Belakang: Indonesia memiliki sejarah yang panjang tentang bencana dan manajemennya. The International Disaster Database melaporkan bahwan antara 1948-2013 terdapat 325 bencana alam yang menyebabkan kerugian materiil dan non-materill tang besar (CRED, 2016). Akan tetapi, banyaknya pengalaman bencana, baik bencana alam maupun bencana akibat ulah manusa, yang sudah dialami, kerugian materiil dan non-materiil pada bencana yang terjadi selanjutnya masih terbilang tinggi. Salah satu usaha untuk mencegah kerugian materiil dan non-materiil akibat bencana adalah meningkatkan kesiapsiagaan terhadap bencana pada seluruh elemen masyarakat, termasuk mahasiswa keperawatan.

Tujuan: Penelitian ini bertujuan untuk mengetahui tingkat kesiapsiagaan bencana pada mahasiswa keperawatan Universitas Harapan Bangsa Purwokerto

Metode: Penelitian ini merupakan penelitian observasional study dengan pendekatan survey. Populasi dalam penelitian ini adalah seluruh mahasiswa keperawatan Universitas Harapan Bangsa Purwokerto. Sampel dalam penelitian ini adalah mahasiswa keperawatan semester enam prodi sarjana dan semester empat diploma dengan teknik pengambilan data secara total sampling. Data diambil dengan menggunakan kuesioner Disaster Preparedness Evaluation Tool: Preparedness Section (DPET:P) yang sudah diterjemahkan ke dalam Bahasa Indonesia dan dimodifikasi sesuai dengan kebutuhan mahasiswa. Data yang terkumpul dianalisis dengan analisis frekuensi sederhana.

Hasil: Secara umum tingkat kesiapsiagaan terhadap bencana mahasiswa keperawatan adalah rendah (rata-rata mean : 1 - 2.99). Mahasiswa melaporkan tingkat kesiapsiagaan yang paling tinggi pada kesiapan untuk melakukan pengambilan keputusan klinis seperti memberikan perawatan pada korban bencana dan pengelolaan respon emosional pasien stress akut dan stres paska trauma. Mahasiswa melaporkan kesiapsiagaan paling rendah pada informasi tentang peranan antar institusi (lokal/provinsi/nasional) dalam tanggap darurat bencana.

Kesimpulan: Tingkat kesiapsiagaan mahasiswa keperawatan Universitas Harapan Bangsa Purwokerto masih rendah.
\end{abstract}

Kata Kunci: Kesiapsiagaan Bencana, Mahasiswa, Keperawatan

\section{PENDAHULUAN}

Sebagai salah satu negara yang rawan terdapat bencana, The International Disaster Database mencatat bahwa telah terjadi lebih dari 325 bencana dalam kurun waktu 1948 2013 (Pusat Penelitian Epidemiologi Bencana/CRED, 2016). Bencana-bencana tersebut mengakibatkan kerugian materiil lebih dari 28 triliun rupiah dengan korban jiwa 190.794 orang (CRED, 2016). Dalam laporannya, Priester (2016) melaporkan bahwa kerugian materiil dan non-materiil terbanyak di Indonesia, disebabkan oleh gempa bumi dan tsunami, meskipun insiden nya lebih sedikit daripada banjir atau tanah longsor.

Studi yang dilakukan The United Nation International Strategy for Disaster Reduction (UNISDR) (2016) mengemukakan bahwa bencana alam merupakan penyebab utama kerugian materiil dan kehilangan jiwa terbesar di Indonesia. Meskipun dampak man-made disaster tidak sebesar bencana alam, bencana tersebut masih menjadi ancaman 
Rizqillah, A.F | Disaster Preparedness: Survey Study pada Mahasiswa Keperawatan Universitas Harapan Bangsa Purwokerto

yang serius bagi seluruh warga Indonesia. Padatnya penduduk Indonesia memperbesar resiko dan dampak dari man-made disaster. Beberapa studi mengemukakan bahwa kecelakaan lalu lintas adalah man-made disaster yang paling sering terjadi dan merenggut paling banyak nyawa di Indonesia (Priester, 2016).

Tingginya kerugian materiil dan kehilangan nyawa akibat bencana perlu ditanggulangi dan dicegah dengan beberapa upaya untuk meningkatkan kesiapsiagaan seluruh elemen masyarakat (Coppola, 2015). Sebagai tenaga kesehatan terbesar dan first responder serta care giver dalam tanggap darurat bencana, perawat dituntut untuk memiliki tingkat kesiapsiagaan bencana yang lebih tinggi daripada masyarakat umum (Perron, Rudge, Blais \& Holmes, 2010; Usher, 2010). Tingkat kesiapsiagaan bencana yang adekuat pada diri perawat dapat meningkatkan rasa percaya diri saat memberikan asuhan keperawatan saat tanggap darurat serta meningkatkan kualitas perawatan yang diberikan (International Council of Nurses/CN, 2009; Ranse, Lenson \& Aimers, 2010).

Sebagai perawat di masa depan, mahasiswa keperawatan diharapkan sudah mulai memupuk tingkat kesiapsiagaan bencana sejak dini. ICN dan WHO (2009) telah mengembangkan kompetensi keperawatan bencana yang diharapkan dapat dipelajari mahasiswa guna mempersiapkan mahasiswa keperawatan untuk turut andil dalam kegiatan tanggap darurat maupun recovery paska bencana. Selain itu, masih tingginya insiden dan kerugian materiil dan non-materiil akibat bencana, mendorong pentingnya implementasi pembelajaran kurikulum kebencanaan dalam proses pendidikan akademik mahasiswa keperawatan (Schmidt et al., 2011).

Di Indonesia belum ada studi yang mendokumentasikan implementasi dan efek yang didapat dari pembelajaran terkait kesiapsiagaan bencana dibangku pendidikan. Meskipun, asosiasi profesi dan himpunan perawat gawat darurat telah memasukkan pelatihan tanggap darurat bencana dalam setiap pelatihan-pelatihan yang diselenggarakan, belum ada studi empirik yang mempelajari tingkat kesiapsiagaan bencana mahasiswa keperawatan secara umum.

\section{METODE}

Penelitian ini merupakan penelitian observasional study dengan pendekatan survey. Penelitian ini dilakukan di Universitas Harapan Bangsa Purwokerto pada bulan Mei-Juli 2018. Populasi dalam penelitian ini adalah seluruh mahasiswa keperawatan Universitas Harapan Bangsa Purwokerto. Sampel dalam penelitian ini adalah mahasiswa keperawatan semester 6 program sarjana dan mahasiswa semester 4 program diploma.

Mahasiswa pada tingkat ini dinilai ideal karena sudah pernah mengikuti praktek klinik keperawatan dan sudah mendapatkan pembelajaran tentang asuhan dan teori keperawatan secara umum. Besar sampel diambil dengan teknik total sampling sehingga didapatkan 180 responden, yang terdiri dari 106 mahasiswa program sarjana dan 74 mahasiswa program diploma.

Instrumen penelitian dalam penelitian 
Rizqillah, A.F | Disaster Preparedness: Survey Study pada Mahasiswa Keperawatan Universitas Harapan Bangsa Purwokerto

ini adalah kuesioner Disaster Preparedness

Evaluation Tool: preparedness section (DPET:

P) yang sudah diterjemahkan ke dalam

Bahasa Indonesia. Instrumen ini sesungguhnya ditujukan untuk mengukur kesiapsiagaan perawat sehingga terdapat beberapa poin sudah dimodifikasi sesuai dengan kebutuhan mahasiswa keperawatan.

Data dari penelitian ini merupakan data numerik yang kemudian dikategorikkan. Nilai mean (SD) 1-2,99 menunjukkan tingkat rendah, 3-4,99 menunjukkan tingkat sedang dan 5-6 menunjukkan tingkat tinggi. Data dari kuesioner DPET: P dikelompokkan kedalam beberapa domain sesuai dengan jenis data yang dikaji. Domain tersebut antara lain Incident Command System (ICS), penanganan psikososial dan kelompok beresiko tinggi, tim dekontaminasi, pengambilan keputusan klinis dan faktor biologis yang berkaitan dengan bencana, kemudian dianalisis dengan analisis deskriptif

\section{HASIL}

Tabel 1 menunjukkan bahwa secara umum tingkat kesiapsiagaan mahasiswa keperawatan Universitas Harapan Bangsa Purwokerto adalah rendah (mean \pm SD : 1 2.99). Pemahaman mahasiswa tentang distribusi perlengkapan dan peran-peran antar institusi lokal/kabupaten/provinsi dan nasional dalam tanggap bencana merupakan hal dengan skor paling rendah (mean: 1.80, SD: 0.61). Sebaliknya, mahasiswa melaporkan memiliki kepercayaan diri yang tinggi untuk mengelola respon emosional pasien dengan stress akut paska trauma (mean: 3.32, SD: 0.67).

Tabel 1. Tingkat Kesiapsiagaan Mahasiswa Keperawatan $(n=180)$

\begin{tabular}{ll}
\hline Kategori & Mean \pm SD \\
\hline Incident Command System (ICS) & \\
$\quad$ Emergency planning dan evakuasi bencana & $2.97 \pm 0.69$ \\
$\quad$ Peran saat tanggap darurat di tempat umum ataupun pribadi & $2.30 \pm 0.75$ \\
$\quad$ Peranan antar institusi (Lokal/provinsi/nasional) dalam tanggap darurat & $1.80 \pm 0.61$ \\
Penanganan masalah psikososial dan kelompok resiko tinggi & \\
$\quad$ Pengkajian adanya post-traumatic syndrome & $2.93 \pm 0.83$ \\
$\quad$ Manajemen stress yang behubungan dengan trauma & $2.96 \pm 0.72$ \\
$\quad$ Melatih kemampuan koping paska trauma & $3.25 \pm 0.71$ \\
$\quad$ Intervensi psikologis seperti terapi perilaku, peer support & $2.58 \pm 0.81$ \\
Dekontaminasi & $2.77 \pm 0.75$ \\
Pengambilan keputusan klinis & \\
$\quad$ Identifikasi adanya stres akut dan stres paska trauma & $3.16 \pm 0.80$ \\
$\quad$ Ruang lingkup peran dalam tanggap darurat bencana & $3.06 \pm 0.91$ \\
$\quad$ Kemampuan memberi perawatan pada korban bencana & $2.91 \pm 0.82$ \\
$\quad$ Manajemen gejala dan respon umum korban bencana yang selamat & $2.87 \pm 0.75$ \\
$\quad$ Pengelolaan respon emosional pasien stress akut paska trauma & $3.32 \pm 0.67$ \\
Faktor biologis terkait bencana & \\
$\quad$ Indikator paparan massa biologis & $2.55 \pm 0.58$ \\
$\quad$ Pengkajian khusus dalam insiden bioterorisme & $2.25 \pm 0.63$ \\
$\quad$ Identifikasi potensi paparan agen bioterorisme dan infeksi & $2.14 \pm 0.69$ \\
$\quad$ Tanda gejala dan pengobatan paparan agen bioterorisme & $2.16 \pm 0.55$ \\
\hline
\end{tabular}


Rizqillah, A.F | Disaster Preparedness: Survey Study pada Mahasiswa Keperawatan Universitas Harapan Bangsa Purwokerto

\section{PEMBAHASAN}

Kesiapsiagaan tentang bencana merupakan hal yang dibekalkan kepada mahasiswa keperawatan secara tidak langsung, tidak melalui mata kuliah ataupun metode pembelajaran tertentu di Indonesia. Meskipun International Council of Nurses (ICN) sudah merekomendasikan kompetensi keperawatan bencana di bangku pendidikan sejak tahun 2009, aplikasinya di Indonesia dan di beberapa negara masih belum maksimal. Akan tetapi, sebagai calon tenaga kesehatan di masa depan, mahasiswa keperawatan memiliki peranan penting dalam proses tanggap darurat maupun rehabilitasi paska bencana.

Mahasiswa keperawatan memerlukan kesiapsiagaan bencana untuk memahami pentingnya peranan mereka dalam manajemen bencana sehingga dapat membantu korban bencana guna mengurangi angka kematian dan kesakitan akibat bencana (Alim et al., 2015). Penelitian ini melaporkan bahwa tingkat kesiapsiagaan mahasiswa keperawatan Universitas Harapan Bangsa Purwokerto masih rendah (mean \pm SD : 1 2.99).

Penelitian ini juga melaporkan bahwa pemahaman tentang peran-peran antar institusi lokal/kabupaten/provinsi dan nasional dalam tanggap bencana merupakan hal yang paling tidak familiar bagi responden. Hal tersebut sesuai dengan penelitian sebelumnya bahwa peranan mahasiswa dan institusi lain terkait tanggap daruat bencana akan berbeda dengan peran mereka dalam kondisi normal tanpa bencana (Baack \& Alfred, 2013; Hope, 2010). Sebuah studi melaporkan bahwa mahasiswa keperawatan dan perawat dapat melakukan beberapa peran lain selain memberikan perawatan pada korban saat tanggap darurat bencana, seperti memberikan pendidikan kesehatan dan menyelesaikan masalah kesehatan dan berkoordinasi dengan institusi lain (Yang, Xiao, Cheng, Zhu, \& Arbon, 2010). Oleh karenanya, pemahaman tentang peranan antar institusi dalam proses tanggap darurat bencana akan lebih mudah dipahami setelah mahasiswa keperawatan memiliki pengalaman dalam tanggap daruat bencana seperti mengikuti kegiatan sukarelawan di daerah yang bencana (Hope, 2010).

Penelitian ini juga melaporkan bahwa responden memiliki kesiapsiagaan yang cukup tinggi untuk mengelola respon emosional pasien dengan stress akut paska trauma (mean: 3.32, SD: 0.67). Hal ini dikarenakan responden telah mendapatkan pengajaran dan pengalaman tentang manajemen emosional pada pasien baik di bangku perkuliahan ataupun selama praktik di Rumah Sakit. Dengan kata lain, responden sudah pernah mendapatkan pengajaran tentang penanganan stress akut paska trauma di bangku pendidikan sehingga meningkatkan kesiapsiagaan mereka dalam memberikan asuhan keperawatan tersebut saat tanggap darurat bencana. Hal tersebut sesuai dengan penelitian Pesiridis dkk (2014) mengemukakan bahwa pendidikan dan pelatihan dapat meningkatkan tingkat kesiapsiagaan perawat secara efektif.

Namun, tingginya kesiapsiagaan dalam manajemen stress paska trauma dalam penelitian ini perlu diperhatikan lebih lanjut mengingat sebagian besar responden belum memiliki pengalaman dalam tanggap darurat 
Rizqillah, A.F | Disaster Preparedness: Survey Study pada Mahasiswa Keperawatan Universitas Harapan Bangsa Purwokerto

bencana. Hal tersebut dikarenakan realita dan kompleksitas tanggap darurat bencana sangat berbeda dengan kondisi normal. Ketegangan dan trauma yang dirasakan oleh masyarakat akan mempengaruhi mahasiswa dalam memberikan asuhan keperawatan. Sehingga mahasiswa keperawatan mungkin akan melaporkan hal yang berbeda setelah mengikuti kegiatan-kegiatan tanggap darurat bencana yang sesungguhnya (Hammad, Arbon \& Gabbie, 2011).

\section{KESIMPULAN DAN SARAN}

Tingkat kesiapsiagaan pada mahasiswa keperawatan terhadap tanggap darurat bencana secara umum masih rendah. Diharapkan peranan antar intitusi baik Lokal/Regional/Nasional/Internasional untuk meberikan pengetahuan dan pelatihan yang cukup mengenai kesiapsiagaan terhadap bencana

\section{DAFTAR PUSTAKA}

Alim, S., Kawabata, M., Nakazawa, M. (2015). Evaluation of disaster preparedness training and disaster drill for nursing students. Nurse Education Today, 35 (1), 25-31.

Baack, S., \& Alfred, D. (2013). Nurses' Preparedness and Perceived Competence in Managing Disasters. Journal of Nursing Scholarship, 45(3), 281-287. doi: 10.1111/jnu.12029

Centre for Research on the Epidemiology of Disaster. (2016). EM-DAT the international Disaster Database. Brussels: Université catholique de Louvain. Retrieved from: http://www.emdat.be/country_profile/ind ex.html

Coppola, D.P. (2015). Introduction to international disaster management. Third edition. Massachusetts: Butterworth-Heinemann.

Hammad, K. S., Arbon, P., \& Gebbie, K. M. (2011). Emergency nurses and disaster response: An exploration of South Australian emergency nurses' knowledge and perceptions of their roles in disaster response. Australasian Emergency Nursing Journal, 14(2), 87-94. doi: 10.1016/j.aenj.2010.10.002

Hope, K. (2010). The willingness of frontline health care workers to work during a public health emergency. Australian Journal of Emergency Management, 25, 39-47. Retrieved from https://ajem.infoservices.com.au/items/A JEM-25-03-09

International Council of Nurses (ICN). (2009). ICN framework of disaster nursing competencies. Available at: http://www.wpro.who.int/hrh/docu ments/icn_framework.pdf?ua $=1$

Perron, A., Rudge, T., Blais, A. \& Holmes, D. (2010) The politics of nursing knowledge and education critical pedagogy in the face of the mili-tarization of nursing in the war on terror. Advances in Nursing Science,33, 184-195.

Pesiridis, T., Sourtzi, P., Galanis, P., \& Kalokairinou, A. (2014). Development, Implementation And Evaluation of $A$ Disaster Training Programme For Nurses: A Switching Replications Randomized Controlled Trial (Vol. 15).

Priester, L. (2016). Monographic issue: An approach to the profile of disaster risk of Indonesia. Emergency and disaster report, 3 (2), 5-66. Retrieved from: http://www.uniovi.net/uied/Emergency_a nd_Disaster_Reports/EDR_3_2_2016_I ndonesia_Dis_Risk_Profile.pdf

Ranse, J, Lenson, S \& Aimers, B. (2010). Black Saturday and the Victorian Bushfires of February 2009: A descriptive survey of nurses who assisted in the pre-hospital setting. Collegian, Vol. 17, pp. 153-159. doi: http://doi.org/10.1016/j.colegn.2010.08.0 02

Schmidt, C.K., Davis, J.M., Sanders, J. L., Chapman, L. A., Cisco, M. C. \& Hady, A. R. (2011). Exploring nursing student's level of preparedness for disaster response. Nursing Education Perspective, 32(6), $380-383$.

United Nation International Strategy for Disaster Reduction. (2016). Indonesia disaster and risk profile. Retrieved from http://www.preventionweb.net/countries/i dn/data/

Usher K. (2010). Editorial: Are we ready? Preparing nurses to respond to disasters 
Rizqillah, A.F | Disaster Preparedness: Survey Study pada Mahasiswa Keperawatan Universitas Harapan Bangsa Purwokerto

$\begin{aligned} & \text { and emerging } \\ & \text { diseases. Journal infectious } \\ & \text { Nursing, 19,143-144. of }\end{aligned}$
10.1111/j.1365-2702.2009.02979.x.

10.1111/j.1365-2702.2009.02979.x.

Yang, Y. N., Xiao, L. D., Cheng, H. Y., Zhu, J.

C., \& Arbon, P. (2010). Chinese nurses' experience in the Wenchuan earthquake relief. International Nursing Review, 57, 217-223 